\title{
The Common Agricultural Policy and the Increased Competitiveness of Spanish Regional Agriculture
}

\author{
Silvia Andrés González-Moralejo ${ }^{1} \&$ Francisco Estruch Sanchís ${ }^{1}$ \\ ${ }^{1}$ Grupo de Economía Internacional y Desarrollo, Universitat Politècnica de València, Valencia, Spain \\ Correspondence: Silvia Andrés González-Moralejo, Grupo de Economía Internacional y Desarrollo, \\ Departamento de Economía y Ciencias Sociales, Universitat Politècnica de València, Edificio 3B ( ${ }^{\circ}$ planta), \\ Camino de Vera, s/n. 46022, Valencia, Spain. Tel: 34-963-877-007-74741. E-mail: silangle@upvnet.upv.es
}

Received: February 28, 2017

Accepted: April 9, $2017 \quad$ Online Published: May 15, 2017

doi:10.5539/jas.v9n6p74

URL: https://doi.org/10.5539/jas.v9n6p74

\begin{abstract}
The cycle of the Common Agricultural Policy reforms begun in 1992 and that finished, for the time being, in 2013, profoundly transformed the agricultural framework of the EU. Taken as a whole, the process consisted of the progressive, partial and asymmetric liberalization of European agriculture, since much more emphasis was placed on dismantling intervention mechanisms than on aiding the restructuring, modernization and adaptation to a more competitive environment. In this context, and with an increasingly more open commercial policy, the States and the regions are obliged to design strategies to increase their competitiveness and innovation within the framework of the current Common Agricultural Policy (2014-2020). This is even more important for the regions most affected by the reforms. Under this argument, this paper reveals the principal qualitative and quantitative unknowns of the regional agricultural policy in Spain after the application of the Health Check in 2008, with special emphasis on the evolution of the Axis 1 of Rural Development.
\end{abstract}

Keywords: agricultural support, Autonomous Communities, Common Agricultural Policy, competitiveness.

JEL codes: Q1-H1.

\section{Introduction}

The EU's Common Agricultural Policy (CAP) was reformed in 2013. Although this reform was not very profound it opened up a new stage in the history of the CAP, since it broke definitively with the historical production and the instruments that incentivized production and distorted the markets. This transformation generated risks and opportunities (Compés \& García, 2013), as well as a certain change in the mentality of the Member States (Atance, 2007). These risks are related to the traumatic changes in the sector that cause reduced activity and populations in certain regions (Compés \& García, 2009). The opportunities include the challenges of sustainability, growth and competitiveness (Massot, 2013), since the reform has put more emphasis on deregulating the markets than on restructuring, modernizing and adapting to a more competitive environment, making manifest the structural weakness of the primary sector and the increasingly precarious situation of the smallest producers, with an impact in Spain that will be influenced by the wide differences among its regions.

The key to the process lies essentially in the elimination of most of the market intervention measures and directing aid to the provision of public goods by the agricultural sector (Massot, 2013). The only measure with regard to the Common Organization of the Single Market was to incorporate the subject of the alimentary chain and tackle the problem of the weak market position of farmers by strengthening producers and inter-professional Organizations. The evolution of the second pillar was not so much to increase the incentives to farmers to make them more competitive, but to increase environmental protection measures and encourage diversity in rural areas. In this regard, the Member States (MS) and the Regions are obliged to design strategies to improve competitiveness and innovation within the framework of the CAP 2014-2020 (Buckwell, 2009) in an ever more open commercial environment.

The boosting of competitiveness in agriculture is included in the European policy of Rural Development, with an Axis 1 of agricultural measures designed to encourage an agricultural model based on competitive, efficient and innovative holdings with higher added values under the control of young professional farmers (Atance, 2006). The Axis 1 aids are increasingly co-financed by national budgets (Cejudo \& Maroto, 2010) and demand an effort 
from those who request them, since the public contribution can reach as much as $40 \%$ of the investment (except for young farmers and residents in disadvantaged areas, who can receive a higher percentage), with the participation of the European Agricultural Fund for Rural Development (EAFRD) of 21\%. This element is crucial in considering these aids, which will be restricted by the scarcity of financial resources both in Europe, where demands are being made to reduce the agricultural budget (Massot, 2010), and even their renationalization (Castillo \& Ramos, 2010), and in Spain, where the economic crisis has imposed severe cuts in public spending that have been applied unequally among the different regions and territories (Regidor \& Troitiño, 2008).

In this context, the questions that can be asked are the following: What is the situation of the different regions of Spanish agriculture in relation to the quantity and nature of public assistance received until 2013? In the ambit of agricultural competitiveness, what strategies have been followed in each of Spain's Autonomous Communities $(\mathrm{AC})$ ? What is their economic impact within the framework of public aids and how was this affected by the CAP's reforms?

Due to their specialization in different products, the starting position of each AC is different, with appreciable differences in the levels of support provided by the CAP, the objectives and instruments. For example, price and market supports may still be important in AC "A", as compared to the policy of budget transfers for rural development practiced in AC "B", or that of decoupled aids in $\mathrm{AC}$ "C". This situation of the decentralized application of agricultural policy is an obstacle to the rational planning of decisions and coordinated public actions if there is no previous mechanism in place of reliable information that allows the effects to be estimated and followed in each $\mathrm{AC}$ in order to correctly diagnose the origin of the problems that the public programs aim to solve, there already being in the literature previous cases of agricultural economy (Atance \& Gómez-Limón, 2004; Philippidis, 2005).

In this context, and in line with the recommendations of the Organization for Economic Cooperation and Development (OECD) (the organization that has been most active, together with the World Trade Organization (WTO) in dismantling price support instruments), the objective of the present work is to orient political decision making as to the strategies to be adopted in the different Spanish regional agricultural sectors as regards competitiveness, efficiency and innovation. For this, the initial situation of the individual ACs will be assessed, using the OECD's advances in estimating agricultural support indicators as a methodological base in order to obtain the following specific goals:

(1) To classify and quantify by regions public aid to Spanish agriculture during the period 2002-2012 by adapting the OECD's method of calculating aid indicators.

(2) Analyze the evolution of public aid to the regions into national and regional contributions.

(3) Examine the evolution of Rural Development Axis 1, the measures included by regions and their economic impact.

(4) Evaluate the scope of the policies that affect Spanish agricultural competitiveness.

The first efforts aimed at estimating regional agricultural support were the works undertaken by the European Commission after the reforms of the nineties, with results for 1994 and 1996 (European Commission, 2001) and for 1991 and 1995 (Tarditi \& Zanias, 2001). These used the concept of Producer Support Estimate introduced by the OECD (OECD, 2007), and also in the study by Zanias (2002) on calculating transfers in the MS. The European Spatial Planning Observation Network (2005) project analyzed the territorial impact of the CAP in 1999 with continental products (i.e. non-Mediterranean) only and calculating the transfers of the "first pillar". Other studies have analyzed transfers in countries with a federal administration, such as Switzerland (Walkenhorst, 2003), Germany (Anders et al., 2004; Hansen, 2005) and the USA (Sumner \& Brunke, 2003). In Spain, the first study on public spending on agriculture in the ACs was by García et al. (1994). The Libro Blanco de la Agricultura y el Desarrollo Rural (MAPA, 2004) was a later work.

The Spanish preoccupation with formulating the follow-up and evaluation of support was responsible for the development of a line of research based on the methodological contribution of the OECD for calculating agricultural support indicators. The most valuable contributions were the discussion of the calculation options of the Market Price Support (MPS) for products not included in the OECD's estimations (Mediterranean products), testing an MSP that measured the percentage differences between domestic and international prices and measuring the customs duty with third countries (García \& Andrés, 2007) and a comparison of the CAP transfers with the support for agriculture in other OECD countries (Andrés \& García, 2010). An application following the WTO methodology can be found in Andrés and García (2016). In addition to the series on Analysis and Perspective by the Spanish Ministry of Agriculture, Food and the Environment (MAFE), in the ambit of 
prospective studies the most important work was carried out by Blanco et al. (2011), which described potential scenarios of the single payment system and analyzed the redistribution effects of these scenarios by means of the CAPRI partial equilibrium model. Its results suggest that the convergence of direct aids would have a minimal impact at the EU level. However, its effects would be highly significant for certain regions and production systems, as in each MS the regions would benefit that historically have received the lowest average payments per hectare, and between States there would be a transfer of funds from the EU-15 to the EU-12. Other studies on the overall European situation have reached similar conclusions (Velázquez, 2008; Zahrnt, 2009; Erjavec et al., 2011; Gocht et al., 2011).

The debate on the competitiveness of agriculture and the evaluation of its regional component has recently been revived. Studies have been published on European agriculture (Hermans et al., 2010), at the national level (Czyzewski \& Stepien, 2011; Popov, 2012; Aggelopoulos et al., 2014), and others on a local level (Fragoso et al., 2011; Cofas \& Toma, 2014; Zasada \& Piorr, 2015). In general, this line of research concludes that the CAP's rural development policies to boost competitiveness have important local effects in their application and in the distribution of funds and that it is becoming essential to promote structural strategies to stimulate the economic competitiveness of holdings in order to increase incomes and rural employment and reduce the long-term tendency to disinvestment and to promote new agricultural and non-agricultural activities in the least competitive zones (Note 1).

\section{Materials and Methods}

Measures of the support to agriculture are included in the OECD's annual publication Agricultural Policies in OECD Countries: Monitoring and Evaluation (2016) (Note 2). The OECD's method consists of calculating and interpreting a wide range of indicators based on the concepts of Producer Support Estimate (PSE), General Services Support Estimate (GSSE) and Total Support Estimate (TSE). The PSE Manual (Note 3) contains a detailed explanation of the concepts, calculation, interpretation and use of each indicator, including how to identify, distinguish and classify the policies and estimate the quantities of the transfers they generate. The statistical series of each member state (the EU is considered as a unit), plus Brazil, Chile, China, the Russian Federation, South Africa and The Ukraine are included in the OECD Database 1986-2015 (Note 4), to complement their annual report.

PSE is an indicator adopted by the OECD to measure support to agriculture: the annual monetary value of gross transfers from consumers and taxpayers to agricultural producers, measured at the farm-gate level, arising from policy measures that support agriculture, regardless of their nature, objectives or impacts on farm production or income. In order to be able to compare support levels in different countries or regions, the PSE is normally expressed as a ratio based on the gross value of the producer's income (\%PSE: PSE as a share of gross farm receipts, including support). The PSE is calculated for individual products and can be added for the purposes of obtaining a national or regional PSE. It is important to note that the emphasis of the PSE lies not only in its total amount, but also in its evolution and distribution among the different support instruments, whose degree of market distortion is variable. There are forms of aid that distort international trade more than others (Blandford, 2005). In general, it tends to accept that transfers through prices imply a greater degree of distortion. The OECD methodology makes it possible to classify support by type, considering on the one hand transfers derived from price interventions and, on the other hand, transfer groups related to disbursements or direct payments to producers. Thus, the PSE includes two types of transfers: a) those that keep domestic prices to the highest (and occasionally lower) producers of the world, forming the component called Market Price Support (MPS); and b) those that provide payments to producers, based on criteria such as the volume produced, the amount of inputs used, the number of animals, the area cultivated or the income received, forming the component called budget transfers.

The OECD also considers the GSSE, the annual monetary value of gross transfers arising from policy measures that create enabling conditions for the primary agricultural sector through development of private or public services, and through institutions and infrastructures regardless of their objectives and impacts on farm production and income, or consumption of farm products. It includes policies where primary agriculture is the main beneficiary, but does not include any payments to individual producers. GSSE transfers do not directly alter producer receipts, costs or consumption expenditures (\%GSSE: GSSE as a share of TSE). Based on the above indicators, the OECD obtains the TSE; this is an indicator of the annual monetary value of all gross transfers from taxpayers and consumers arising from policy measures that support agriculture, net of associated budgetary receipts, regardless of their objectives and impacts on farm production and income, or consumption of farm products. The TSE is the sum of transfers or payments to producers (PSE), structural actions (GSSE) and transfers or payments of taxpayers to consumers (direct subsidy to the first consumer). The percentage TSE 
(\%TSE) expresses general support as a percentage of GDP. Table 1 gives a breakdown of the indicators according to the type of aid they contain, including an algebraic detail about their calculation methodology. For more information, readers can consult the PSE Manual (Note 3).

Table 1. Support categories from the OECD indicators

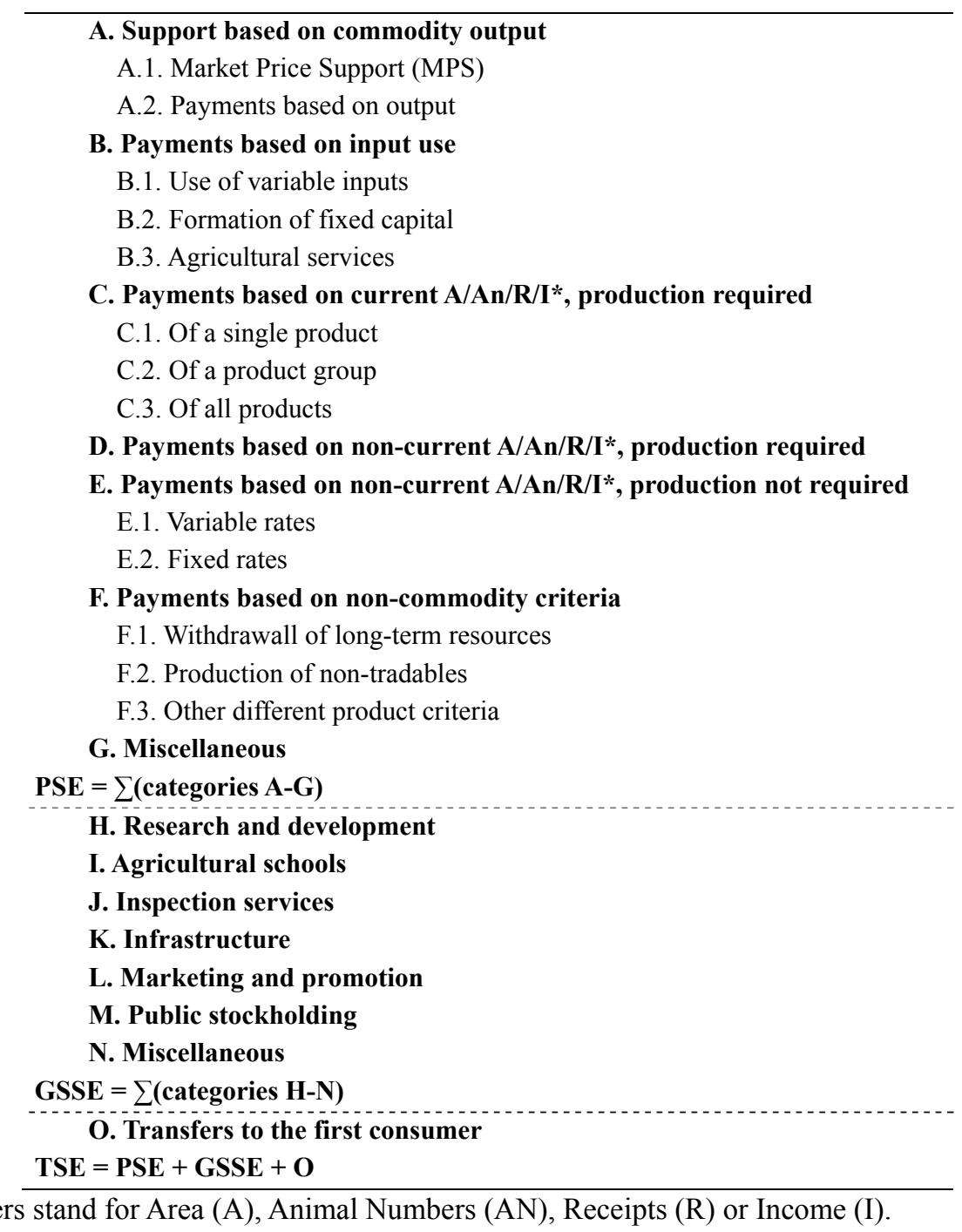

Note. * The letters stand for Area (A), Animal Numbers (AN), Receipts (R) or Income (I).

Source: Compiled by the authors from PSE Manual.

The present study calculated the OECD indicators for the period 2002-2013 for Spain and each of its ACs, according to the origin of the transfers (Spanish or European). In this way:

- $\quad$ TOTAL TSE $=$ NATIONAL TSE + CAP TSE

- $\quad$ TOTAL PSE $=$ NATIONAL PSE + CAP PSE

- TOTAL GSSE = NATIONAL GSSE + CAP GSSE

In calculating Spanish transfers, the budgetary transfers were obtained from information from the Subdirección General de Relaciones Internacionales y Asuntos Comunitarios of the MAFE, which gives the figures for state and AC transfers for the period 2005-2013. The co-financed measures of rural development for the period 2007-2013 (Note 5) were taken from the Rural Development Programs financed by the EAFRD for each AC (national figure). To calculate CAP support by regions, the figures for the transfers were taken from the Reports on the Activities of the Spanish Agricultural Guarantee Fund, which contain the European Agricultural Guidance and Guarantee Fund-Guarantee and European Agricultural Guarantee Fund to the ACs. Between 2002 and 2006 
the European Agricultural Guidance and Guarantee Fund-Guidance (Note 6) transfers were incorporated, as well as the agricultural transfers of the Regional Operative Programs for 2000-2006, basically associated with the financing of structural actions (Note 7) in the sector. From 2007, rural development measures were taken from the Rural Development Programs financed by the EAFRD for each AC (EAFRD figures), plus agricultural transfers from the Regional Operative Programs for 2007-2013 (Note 8).

\section{Results}

\subsection{The Size of Public Support for Spanish Agriculture}

The support to Spanish agriculture is mainly concentrated on Andalusia, Castilla-La Mancha, Castilla \& León, Catalonia and Aragón, regions with large agricultural sectors (as determined by their Productin figures (PRA), Useful Tillage Surface (SAU) and Agricultural Work Units (UTA)). Except for Catalonia, their PRA contributes a large percentage to the regional GDP (Note 9). Their evolution shows a clear tendency towards reduced activities for reasons that will be explained in the subsequent sections of this paper. As can be seen in Table 2, the total support received by each AC (TOTAL TSE) is the sum of transfers from within Spain (NATIONAL TSE) and the EU (CAP TSE).

Table 2. Estimated Total Support (TOTAL TSE) by AC ( $€$ million)

\begin{tabular}{|c|c|c|c|c|c|c|}
\hline & \multirow{2}{*}{\multicolumn{3}{|c|}{$\begin{array}{l}\text { MEAN ANNUAL 2006-2009 } \\
\text { CAP MID-TERM REVIEW }\end{array}$}} & \multirow{2}{*}{\multicolumn{3}{|c|}{$\begin{array}{c}\text { MEAN ANNUAL 2010-2013 } \\
\text { CAP HEALTH CHECK }\end{array}$}} \\
\hline & & & & & & \\
\hline & NATIONAL TSE & CAP TSE & TOTAL TSE & NATIONAL TSE & CAP TSE & TOTAL TSE \\
\hline GALICIA & 78.2 & 488.7 & 566.9 & 92.0 & 441.8 & 533.8 \\
\hline ASTURIAS (P. de) & 22.7 & 153.7 & 176.3 & 22.6 & 127.7 & 150.3 \\
\hline CANTABRIA & 21.9 & 84.0 & 105.9 & 17.9 & 72.2 & 90.0 \\
\hline BASQUE COUNTRY & 13.3 & 118.0 & 131.4 & 21.7 & 89.5 & 111.2 \\
\hline NAVARRA (C.F. de) & 46.1 & 213.2 & 259.3 & 35.3 & 173.0 & 208.3 \\
\hline LA RIOJA & 35.9 & 92.1 & 128.0 & 20.2 & 67.7 & 87.8 \\
\hline ARAGÓN & 112.7 & 796.2 & 908.9 & 75.8 & 628.6 & 704.4 \\
\hline CATALONIA & 124.5 & 823.9 & 948.4 & 97.8 & 586.4 & 684.2 \\
\hline BALEARIC (Islands) & 11.0 & 71.8 & 82.8 & 8.4 & 43.4 & 51.8 \\
\hline CASTILLA \& LEÓN & 193.3 & 1546.6 & 1739.8 & 164.6 & 1282.6 & 1447.1 \\
\hline MADRID (Com.) & 10.2 & 146.5 & 156.6 & 9.2 & 82.0 & 91.2 \\
\hline CASTILLA LA MANCHA & 164.7 & 1189.5 & 1354.2 & 94.5 & 1042.9 & 1137.4 \\
\hline VALENCIA & 88.8 & 538.8 & 627.5 & 76.4 & 371.5 & 447.8 \\
\hline MURCIA (R. de) & 26.7 & 300.8 & 327.5 & 33.0 & 228.0 & 261.1 \\
\hline EXTREMADURA & 65.3 & 802.7 & 867.9 & 61.6 & 704.3 & 765.9 \\
\hline ANDALUSIA & 202.2 & 2810.5 & 3012.6 & 155.2 & 2313.6 & 2468.9 \\
\hline CANARY (Islands) & 15.8 & 262.7 & 278.4 & 21.6 & 322.7 & 344.3 \\
\hline TOTAL SPAIN & $1,233.0$ & $10,439.3$ & $11,672.2$ & $1,007.7$ & $8,577.7$ & $\mathbf{9 , 5 8 5 . 4}$ \\
\hline
\end{tabular}

Source: Compiled by the authors.

\subsubsection{Transfers from Spain: Composition and Characteristics}

The transfers from inside Spain include the co-financing of rural development measures and transfers from the central government in Madrid and those from the regional governments. These transfers do not include production-based payments (PSE Category A) and most of them are structural measures (GSSE) when compared with the EU transfers ( $8 \%$ of state aids, $34 \%$ of co-financed rural development and over $50 \%$ of regional aids). These figures reveal the role of state aid as a supplement to the financing of services provided to the agricultural sector in general. As the rural development measures are co-financed, they are mostly given to individual holdings as provided by the CAP, especially in the PSE Categories B, C and F (setting up young farmers, investments in agriculture and modernization, training and advising, agri-environmental aid, aid to disadvantaged areas, conversion of agricultural land to forests, etc.). Also important are the aids to developing infrastructures within the GSSE in Categories K and N. An even higher percentage of the state aids are provided to individual producers and are concentrated in PSE Category B on financing the use of variable inputs (aids to agricultural insurance) and fixed inputs (e.g. machinery renewals and stock-breeding). The small proportion 
dedicated to general services supports promotion and marketing activities, pest control, and aids to Sanitary Defense Groups (Categories L and N). The aids from the regional governments are given to individual producers in PSE Categories B and G (aids to insurance and fuel, modernization, sustainable production, acquiring land and machinery, bee-keeping, stock-breeding, compensation for adverse weather, etc.). A large amount is concentrated in general services through developing infrastructures, promotion and marketing and health measures (Categories K, L and N).

Figure 1 shows the composition of support from within Spain by the origin of the transfers. The biggest contribution to the NATIONAL TSE, almost $50 \%$, is from co-financed rural development, followed by state transfers, with an average weight of $35 \%$, while regional support is only $15 \%$. The NATIONAL PSE is composed of co-financed rural development $(45 \%)$ and state transfers $(45 \%)$, regional support (10\%). NATIONAL GSSE is formed by co-financed rural development (61\%), regional transfers $(29 \%)$, while the state contribution is $10 \%$.

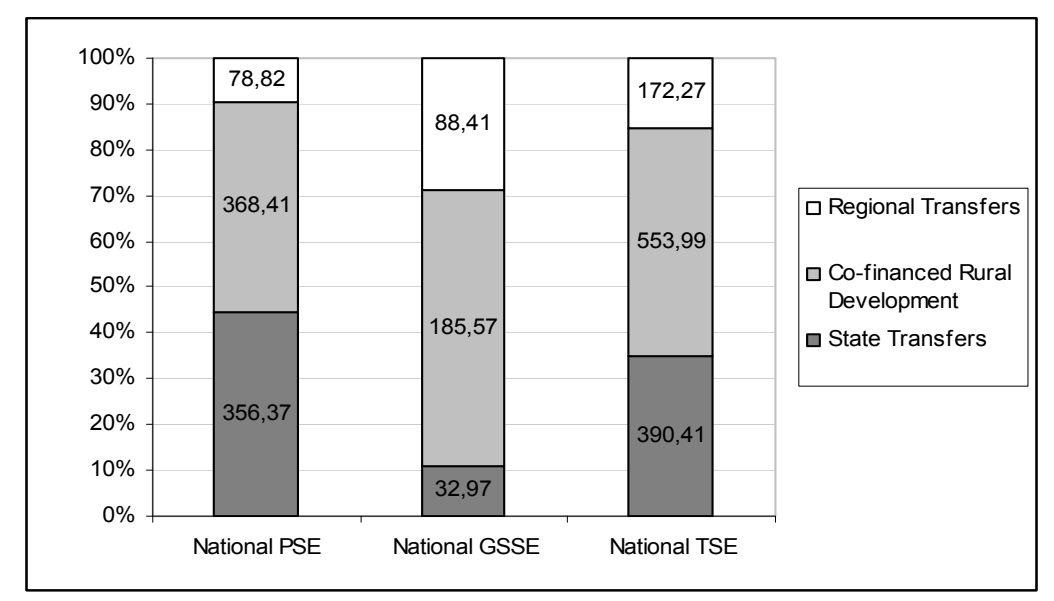

Figure 1. Composition of national aids. Average 2005-2013 ( $€$ million)

Source: Compiled by the authors.

Table 3. Principal indicators of the OECD in Spain (€ million)

\begin{tabular}{llllllllll}
\hline & $\mathbf{2 0 0 5}$ & $\mathbf{2 0 0 6}$ & $\mathbf{2 0 0 7}$ & $\mathbf{2 0 0 8}$ & $\mathbf{2 0 0 9}$ & $\mathbf{2 0 1 0}$ & $\mathbf{2 0 1 1}$ & $\mathbf{2 0 1 2}$ & $\mathbf{2 0 1 3}$ \\
\hline PSEcap & 10887.48 & $9,730.05$ & $9,299.77$ & $9,220.46$ & $8,992.98$ & $8,088.83$ & $7,503.59$ & $8,231.15$ & $8,117.95$ \\
PSEnational & 807.60 & 917.47 & 679.98 & 898.85 & 952.49 & 892.37 & 797.03 & 731.00 & 570.60 \\
TOTAL PSE & $\mathbf{1 1 6 9 5 . 0 8}$ & $\mathbf{1 0} 647.52$ & $\mathbf{9 , 9 7 9 . 7 5}$ & $\mathbf{1 0} \mathbf{1 1 9 . 3 1}$ & $\mathbf{9 , 9 4 5 . 4 7}$ & $\mathbf{8 , 9 8 1 . 2 0}$ & $\mathbf{8 , 3 0 0 . 6 2}$ & $\mathbf{8 , 9 6 2 . 1 5}$ & $\mathbf{8 , 6 8 8 . 5 6}$ \\
\hline \% PSEcap & 27.49 & 26.17 & 21.89 & 22.17 & 23.70 & 20.04 & 18.32 & 19.51 & 18.34 \\
\% PSEnational & 2.04 & 2.47 & 1.60 & 2.16 & 2.51 & 2.21 & 1.95 & 1.73 & 1.29 \\
\% TOTAL PSEe & $\mathbf{2 9 . 5 3}$ & $\mathbf{2 8 . 6 4}$ & $\mathbf{2 3 . 4 9}$ & $\mathbf{2 4 . 3 3}$ & $\mathbf{2 6 . 2 1}$ & $\mathbf{2 2 . 2 5}$ & $\mathbf{2 0 . 2 6}$ & $\mathbf{2 1 . 2 4}$ & $\mathbf{1 9 . 6 3}$ \\
\hline GSSEcap & $1,553.65$ & $1,543.17$ & 269.80 & 410.56 & 436.69 & 453.06 & 513.49 & 466.77 & 360.41 \\
GSSEnational & 292.50 & 453.31 & 236.80 & 337.19 & 411.32 & 361.26 & 322.60 & 212.75 & 142.51 \\
TOTAL GSSEe & $\mathbf{1 , 8 4 6 . 1 5}$ & $\mathbf{1 , 9 9 6 . 4 7}$ & $\mathbf{5 0 6 . 6 0}$ & $\mathbf{7 4 7 . 7 4}$ & $\mathbf{8 4 8 . 0 1}$ & $\mathbf{8 1 4 . 3 3}$ & $\mathbf{8 3 6 . 0 9}$ & $\mathbf{6 7 9 . 5 1}$ & $\mathbf{5 0 2 . 9 2}$ \\
\hline \% GSSEcap & 11.71 & 13.00 & 2.68 & 4.09 & 4.46 & 5.08 & 6.31 & 5.33 & 4.24 \\
\% GSSEnational & 26.58 & 32.80 & 25.68 & 26.98 & 29.85 & 28.80 & 28.81 & 22.54 & 19.98 \\
\% TOTAL GSSEe & $\mathbf{1 2 . 8 5}$ & $\mathbf{1 5 . 0 7}$ & $\mathbf{4 . 6 1}$ & $\mathbf{6 . 6 2}$ & $\mathbf{7 . 6 0}$ & $\mathbf{8 . 0 0}$ & $\mathbf{9 . 0 3}$ & $\mathbf{7 . 0 0}$ & $\mathbf{5 . 4 6}$ \\
TSEcap & 13266.61 & 11868.37 & 10067.07 & 10039.67 & $9,781.96$ & $8,918.53$ & $8,141.35$ & $8,758.59$ & $8,492.27$ \\
TSEnational & $1,100.30$ & $1,381.94$ & 922.16 & $1,249.99$ & $1,377.76$ & $1,254.29$ & $1,119.63$ & 943.74 & 713.11 \\
TOTAL TSEe & $\mathbf{1 4 3 6 6 . 9 1}$ & $\mathbf{1 3 2 5 0 . 3 2}$ & $\mathbf{1 0} \mathbf{9 8 9 . 2 2}$ & $\mathbf{1 1} \mathbf{2 8 9 . 6 6}$ & $\mathbf{1 1} \mathbf{1 5 9 . 7 2}$ & $\mathbf{1 0} \mathbf{1 7 2 . 8 2}$ & $\mathbf{9 , 2 6 0 . 9 8}$ & $\mathbf{9 , 7 0 2 . 3 3}$ & $\mathbf{9 , 2 0 5 . 3 8}$ \\
\hdashline \% TSEcap & 1.46 & 1.20 & 0.96 & 0.92 & 0.93 & 0.85 & 0.78 & 0.85 & 0.83 \\
\% TSEnational & 0.12 & 0.14 & 0.09 & 0.11 & 0.13 & 0.12 & 0.11 & 0.09 & 0,07 \\
\% TOTAL TSEe & $\mathbf{1 . 5 8}$ & $\mathbf{1 . 3 4}$ & $\mathbf{1 . 0 4}$ & $\mathbf{1 . 0 4}$ & $\mathbf{1 . 0 7}$ & $\mathbf{0 . 9 7}$ & $\mathbf{0 . 8 9}$ & $\mathbf{0 . 9 4}$ & $\mathbf{0 . 9 0}$ \\
\hline
\end{tabular}

Source: Compiled by the authors. 
Table 3 shows a comparison between the national and European transfers (see Section 3.1.2). Of the total support received by the Spanish producer (TOTAL PSE), $8.3 \%$ is from the Spanish government. TOTAL PSE was $€ 8,700 \mathrm{~m}$ in 2013 , a reduction of $26 \%$ over 2005 , or $20 \%$ of the producers' incomes, (the average of the EU and the OECD) (Note 10). State support was increased to $36 \%$ when considering total support to general services (TOTAL GSSE). Total GSSE represents $8.5 \%$ of total support (very much lower than the average EU and OECD values). In short, Spain and its Autonomous Communities finance approximately $10 \%$ of the total support to agriculture (TOTAL TSE), which has gone down by $36 \%$ in nine years. This was $€ 9,200 \mathrm{~m}$ in 2013 , or $0.9 \%$ of GDP (somewhat higher than in the EU and OECD).

\subsubsection{Who Finances the EU Transfers?}

Table 4 shows that Spain received an annual average of $€ 11$ 100m in CAP TSE between 2002 and 2013. The CAP contributions can be seen to fall from $€ 14300 \mathrm{~m}$ in 2002 to $€ 8,500 \mathrm{~m}$ in 2013 . The measures in which these CAP transfers were made will be given below (general service and producer support).

Table 4. Estimated Total Support by AC derived from CAP transfers ( $€$ million)

\begin{tabular}{|c|c|c|c|c|c|c|}
\hline & $\begin{array}{l}\text { MEAN ANNUAL } \\
\text { 2002-2005 } \\
\text { AGENDA 2000 }\end{array}$ & $\begin{array}{l}\text { MEAN ANNUAL } \\
\text { 2006-2009 } \\
\text { CAP MID-TERM } \\
\text { REVIEW }\end{array}$ & $\begin{array}{c}\text { MEAN ANNUAL } \\
2010-2013 \\
\text { CAP HEALTH } \\
\text { CHECK }\end{array}$ & $\begin{array}{l}\text { MEAN } \\
\text { 2002-2013 }\end{array}$ & $\begin{array}{l}\text { 2002-2013 } \\
\text { (\%) }\end{array}$ & $\begin{array}{l}2013 / 2002 \\
(2002=100)\end{array}$ \\
\hline & TSE PAC & TSE PAC & TSE PAC & & & \\
\hline GALICIA & 798.8 & 488.7 & 441.8 & 576.4 & 5.2 & 56.5 \\
\hline ASTURIAS (P. de) & 245.7 & 153.7 & 127.7 & 175.7 & 1.6 & 43.5 \\
\hline CANTABRIA & 149.8 & 84.0 & 72.2 & 102 & 0.9 & 51.4 \\
\hline BASQUE COUNTRY & 192.3 & 118.0 & 89.5 & 133.3 & 1.2 & 46.6 \\
\hline NAVARRA (C.F. de) & 294.9 & 213.2 & 173.0 & 227 & 2 & 55.3 \\
\hline LA RIOJA & 134.2 & 92.1 & 67.7 & 98 & 0.9 & 52.6 \\
\hline ARAGÓN & $1,122.4$ & 796.2 & 628.6 & 849.1 & 7.6 & 58.7 \\
\hline CATALONIA & $1,242.1$ & 823.9 & 587.2 & 884.4 & 8 & 50 \\
\hline BALEARIC (Islands) & 110.9 & 71.8 & 43.4 & 75.3 & 0.7 & 41 \\
\hline CASTILLA \& LEÓN & $2,212.1$ & $1,546.6$ & $1,282.6$ & $1,680.40$ & 15.1 & 59.2 \\
\hline MADRID (Com.) & 201.5 & 146.5 & 82.0 & 143.3 & 1.3 & 36.2 \\
\hline CASTILLA LA MANCHA & $1,425.5$ & $1,189.5$ & $1,047.2$ & $1,220.70$ & 11 & 67.7 \\
\hline VALENCIA & 795.8 & 538.8 & 371.5 & 568.7 & 5.1 & 49.2 \\
\hline MURCIA (R. de) & 464.4 & 300.8 & 228.0 & 331.1 & 3 & 58 \\
\hline EXTREMADURA & 896.2 & 802.7 & 704.3 & 801 & 7.2 & 77.5 \\
\hline ANDALUSIA & $3,703.4$ & $2,810.5$ & $2,313.6$ & $2,942.50$ & 26.5 & 55.6 \\
\hline CANARY (Islands) & 295.6 & 262.7 & 322.7 & 293.6 & 2.6 & 112.7 \\
\hline TOTAL SPAIN & 14285.2 & 10439.3 & $8,577.7$ & 11102.4 & 100 & 58.6 \\
\hline
\end{tabular}

Source: Compiled by the authors.

The concentration of total support in Andalusia, Castilla \& León, Castilla-La Mancha, Catalonia, Aragón and Extremadura shows the relatively higher support to the sub-sectors: sheep and goat rearing, beef cattle, wine, cereals and olive oil, with differences between the continental agricultural regions (highly subsidized) and the fruit and vegetable regions. Spanish agriculture is undoubtedly diverse and complex. Its geographical size, topography and climatic variations imply considerable differences in the production of the different regions. These differences can be seen in Table 4 in the territorial distribution of total CAP support. Another fundamental difference between the ACs lies in the way support is provided, with important production-based payments in specialized regions (dairy products in Galicia, and fruit and vegetables in the Mediterranean areas) while in other regions most support is given in the form of direct payments not related to production (Andalusia, Aragón, both Castillas and Extremadura).

The growth of GDP and the reduced total support in nominal terms have led to a significant drop in CAP TSE as a percentage of GDP (from $1.99 \%$ to $0.83 \%$ ), still above the EU and OECD average $(0.75 \%)$ (Note 11 ). Extremadura and both Castillas receive the relatively high values of over 3\%, while Asturias, Cantabria, The 
Basque Country, Catalonia, Valencia and Madrid the figure does not reach 1\%, as can be seen in Map 1, in which the Mediterranean Regions and Cantabria show lower CAP TSE values than the south and central mainland.

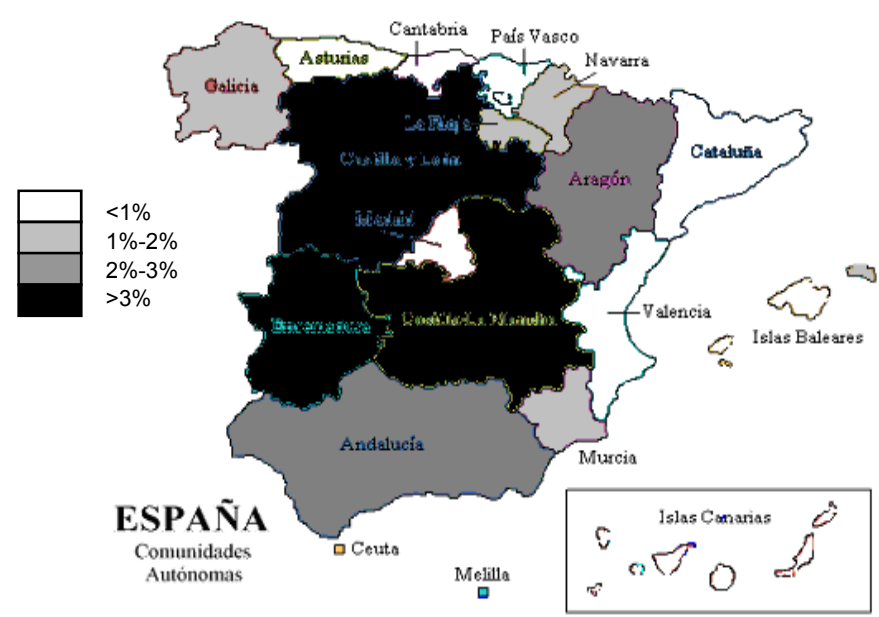

Map 1. Estimated Total Support per AC: \% of GDP (average 2002-2013)

Source: Compiled by the authors.

\section{(1) Transfers for Support to General Services and the Loss of EU Co-Financing}

The General Services Support to Agriculture from CAP transfers, shown in Table 5, was €360m in 2013. Five ACs received almost $60 \%$ of the CAP GSSE: Andalusia (18.0\%), Castilla \& León (12.7\%), Castilla-La Mancha (9.3\%), Galicia (8.9\%) and The Canary islands (8.5\%). The northern ACs (Asturias, Cantabria, Basque Country, La Rioja) while Madrid received a little over 1\%. In 2007-2013 the most important CAP GSSE measures: aids to added value of agriculture and forestry products and aids to infrastructures for the development and adaptation of agriculture and forestry (Category K) were significant in Andalusia, both Castillas, Extremadura and The Canaries. Measures for early retirement and for business creation and development (Category $\mathrm{K}$ ) had considerable weight in Galicia. Promotion of wines and spirits were important in the traditional wine-producing regions such as Castilla-La Mancha, Castilla \& León, La Rioja and Galicia. In fruit and vegetable growing regions such as Andalusia and Valencia, aids to Operating Funds of Producers' Organizations headed the list.

The CAP GSSE and its tendency to fall, shown in Table 5, are influenced by two factors. In the period 2007-2013, six regions no longer fulfilled the conditions of Objective 1, which involved reductions in their structural transfers. In this framework, Andalusía, Castilla-La Mancha, Extremadura and Galicia remained in the Convergence Objective; Asturias, Murcia, Castilla \& León, Valencia and The Canaries entered the Phasing-Out and Phasing-In Objectives; and Aragón, The Balearics, Cantabria, Catalonia, Madrid, Navarra, The Basque Country and La Rioja remained in the Regional Competitiveness and Employment Objective. Table 5 shows the financial breakdown of these events, as well as the elimination of the Operative Programs in force until 2006, whose funds are included in the CAP GSSE in the present study. However, since 2007 only the structural measures financed by the EAGF and EAFRD are included, as can be seen in Figure 2. In the last seven years of this period, the CAP GSSE rose from $€ 270 \mathrm{~m}$ to more than $€ 510 \mathrm{~m}$ in 2011 , but in the last two years of the Health Check (2012 and 2013), when the economic crisis reached a peak, this figure was reduced by $30 \%$ to the $€ 360 \mathrm{~m}$ cited above. 
Table 5. Estimated Support to General Services per AC from CAP transfers (€ million)

\begin{tabular}{|c|c|c|c|c|c|c|}
\hline & $\begin{array}{l}\text { MEAN ANNUAL } \\
\text { 2002-2005 } \\
\text { AGENDA } 2000\end{array}$ & $\begin{array}{c}\text { MEAN ANNUAL } \\
\text { 2006-2009 } \\
\text { CAP MID-TERM } \\
\text { REVIEW }\end{array}$ & $\begin{array}{c}\text { MEAN ANNUAL } \\
\text { 2010-2013 } \\
\text { CAP HEALTH } \\
\text { CHECK }\end{array}$ & $\begin{array}{l}\text { MEAN } \\
\text { 2002-2013 }\end{array}$ & $\begin{array}{l}\text { 2002-2013 } \\
(\%)\end{array}$ & $\begin{array}{l}2013 / 2002 \\
(2002=100)\end{array}$ \\
\hline & GSSE PAC & GSSE PAC & GSSE PAC & & & \\
\hline GALICIA & 158.3 & 53.8 & 28.7 & 80.3 & 8.9 & 8 \\
\hline ASTURIAS (P. de) & 43.3 & 25.7 & 13.6 & 27.5 & 3.1 & 12.7 \\
\hline CANTABRIA & 19.8 & 6.1 & 5.4 & 10.4 & 1.2 & 11.6 \\
\hline BASQUE COUNTRY & 21.3 & 7.1 & 7.2 & 11.9 & 1.3 & 39.5 \\
\hline NAVARRA (C.F. de) & 29.5 & 12.0 & 11.2 & 17.6 & 1.9 & 27.3 \\
\hline LA RIOJA & 17.1 & 7.3 & 8.7 & 11 & 1.2 & 60.5 \\
\hline ARAGÓN & 108.4 & 42.2 & 22.3 & 57.6 & 6.4 & 15.6 \\
\hline CATALONIA & 88.1 & 43.5 & 28.8 & 53.5 & 5.9 & 36.8 \\
\hline BALEARIC (Islands) & 12.8 & 4.1 & 1.2 & 6 & 0.7 & 6.4 \\
\hline CASTILLA \& LEÓN & 236.9 & 68.8 & 36.6 & 114.1 & 12.7 & 14.8 \\
\hline MADRID (Com.) & 24.3 & 7.4 & 3.6 & 11.7 & 1.3 & 11.4 \\
\hline CASTILLA LA MANCHA & 159.4 & 56.8 & 34.5 & 83.5 & 9.3 & 16.3 \\
\hline VALENCIA & 94.8 & 53.4 & 40.2 & 62.8 & 7 & 36.8 \\
\hline MURCIA (R. de) & 66.9 & 50.1 & 50.6 & 55.9 & 6.2 & 75.4 \\
\hline EXTREMADURA & 105.7 & 34.1 & 36.7 & 58.8 & 6.5 & 30.2 \\
\hline ANDALUSIA & 273.4 & 106.3 & 107.8 & 162.5 & 18 & 27.1 \\
\hline CANARY (Islands) & 132.4 & 86.5 & 11.7 & 76.8 & 8.5 & 3.7 \\
\hline TOTAL SPAIN & $1,592.2$ & 665.1 & 448.5 & 901.9 & 100 & 22.1 \\
\hline
\end{tabular}

Source: Compiled by the authors.

Map 2 shows the percentage CAP GSSE, which in Spain was around 4\% in 2013, quite different from the European and OECD averages (10.7 and 12.69\%, respectively) (Note 12). The lower European values point out the need to provide the second pillar of the CAP with more funds.

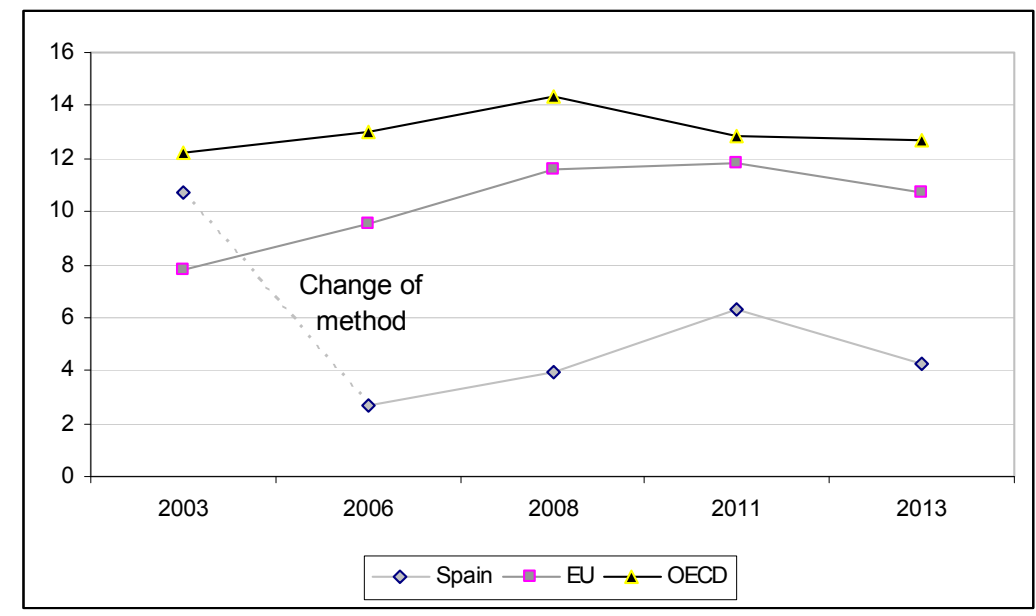

Figure 2. Evolution of $\%$ GSSE (2002-2013)

Source: Compiled by the authors. 


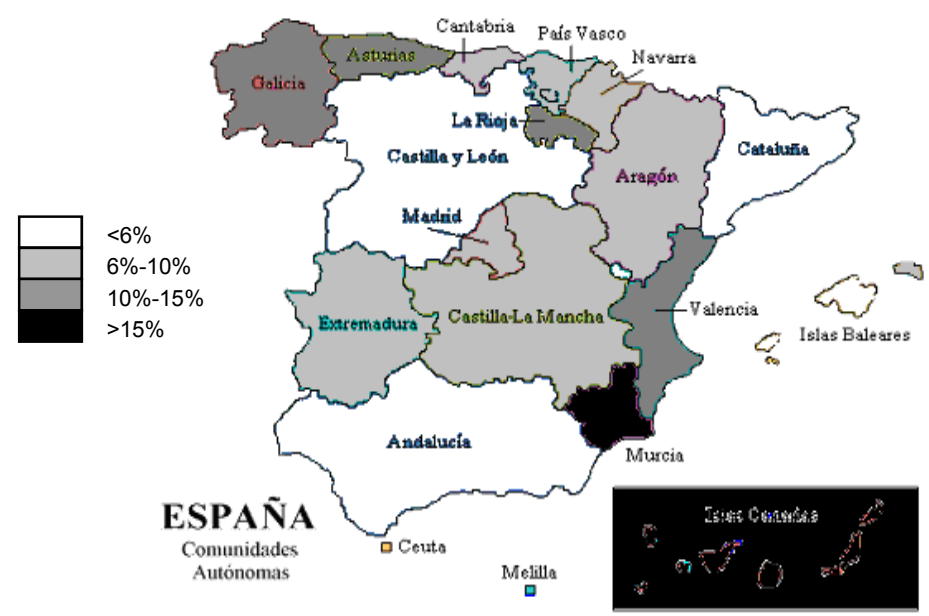

Map 2. Estimated Support to General Services per AC: \% CAP TSE (average 2002-2013)

Source: Compiled by the authors.

(2) Estimated Support to Producers and the Challenge to European Agricultural Reform

The CAP PSE indicator is shown in Table 6 , in which the annual average figure is $€ 9,700 \mathrm{~m}$ for the period. The reduction of aids to producers is quite clear, i.e. 33\% between 2002 and 2013. The CAP PSE can be seen to be concentrated in four ACs: Andalusia (27.42\%), Castilla \& León (15.96\%), Castilla-La Mancha (10.49\%) and Catalonia (8.13\%). Apart from The Canaries, all the regions have lost CAP PSE to varying degrees. Those that lost least were Extremadura $(8.11 \%)$ and Castilla-La Mancha $(16.77 \%)$. Category B measures, such as restructuring and reconversion of vineyards, and the Category $\mathrm{C}$, such as the suckler cow premium and agri-environmental aids remained stable at high values in these regions, and the single payment of the Mid-Term Reform entered strongly. The north of Spain (Asturias, The Basque Country and La Rioja) and Madrid were at the other extreme, and lost $50 \%$ due to the drop in production-based aids (Category A), premiums for stock rearing and aids for cereals (Category C), aids to modernizing holdings and investments in holdings (Category B). In The Canaries, the support given to producers doubled with respect to the 2002 figure, which was due to this region being a peripheral EU zone and receiving funds from the Program of Specific Options for the Canary Islands (POSEICAN) (Note 13).

The\% CAP PSE was $18.4 \%$ in 2013, quite similar to that of the OECD (18.2\%) but somewhat lower than the EU average (19.8\%) (Note 14). Map 3 shows the percentage income of producers from CAP transfers: in Murcia and La Rioja it is below 15\%, while Asturias, Cantabria, Extremadura and Madrid are the leaders with figures over $30 \%$. These differences are due to each of the regions specializing in different products and the fact that the products of the North and West of Spain receive higher support from the EU. 
Table 6. Estimated Support to Producers by AC from CAP transfers ( $€$ million)

\begin{tabular}{|c|c|c|c|c|c|c|}
\hline & $\begin{array}{c}\text { MEAN ANNUAL } \\
\text { 2002-2005 } \\
\text { AGENDA } 2000\end{array}$ & $\begin{array}{c}\text { MEAN ANNUAL } \\
2006-2009 \\
\text { CAP MID-TERM } \\
\text { REVIEW } \\
\end{array}$ & $\begin{array}{c}\text { MEAN ANNUAL } \\
2010-2013 \\
\text { CAP HEALTH } \\
\text { CHECK } \\
\end{array}$ & $\begin{array}{l}\text { MEAN } \\
2002-2013\end{array}$ & $\begin{array}{l}2002-2013 \\
(\%)\end{array}$ & $\begin{array}{l}2013 / 2002 \\
(2002=100)\end{array}$ \\
\hline & PSE PAC & PSE PAC & PSE PAC & & & \\
\hline GALICIA & 628.6 & 433.1 & 412.9 & 491.5 & 5.1 & 70.1 \\
\hline ASTURIAS (P. de) & 199.5 & 127.2 & 114.1 & 146.9 & 1.5 & 50.8 \\
\hline CANTABRIA & 129.0 & 77.8 & 66.8 & 91.2 & 0.9 & 57.5 \\
\hline BASQUE COUNTRY & 169.5 & 110.0 & 81.8 & 120.4 & 1.2 & 48 \\
\hline NAVARRA (C.F. de) & 252.4 & 189.3 & 156.5 & 199.4 & 2 & 61.1 \\
\hline LA RIOJA & 114.1 & 82.6 & 57.5 & 84.7 & 0.9 & 52 \\
\hline ARAGÓN & 940.8 & 706.7 & 584.3 & 743.9 & 7.6 & 68.9 \\
\hline CATALONIA & 1082.0 & 743.3 & 546.6 & 790.7 & 8.1 & 54.8 \\
\hline BALEARIC (Islands) & 97.7 & 67.4 & 42.1 & 69.1 & 0.7 & 45.9 \\
\hline CASTILLA \& LEÓN & $1,961.4$ & $1,461.7$ & $1,234.9$ & $1,552.6$ & 16 & 64.8 \\
\hline MADRID (Com.) & 174.6 & 137.7 & 77.8 & 130 & 1.3 & 39.2 \\
\hline CASTILLA LA MANCHA & $1,100.1$ & 987.7 & 973.1 & $1,020.3$ & 10.5 & 83.2 \\
\hline VALENCIA & 639.3 & 423.0 & 316.4 & 459.5 & 4.7 & 56 \\
\hline MURCIA (R. de) & 370.8 & 226.7 & 174.3 & 257.2 & 2.6 & 59.9 \\
\hline EXTREMADURA & 714.2 & 729.7 & 655.7 & 699.9 & 7.2 & 91.9 \\
\hline ANDALUSIA & $3,153.1$ & $2,655.5$ & $2,191.8$ & $2,666.8$ & 27.4 & 62.5 \\
\hline CANARY (Islands) & 150.0 & 151.5 & 304.2 & 201.9 & 2.1 & 214.9 \\
\hline TOTAL SPAIN & 11876.8 & $9,310.8$ & $7,990.3$ & 9,726 & 100 & 67.1 \\
\hline
\end{tabular}

Source: Compiled by the authors.

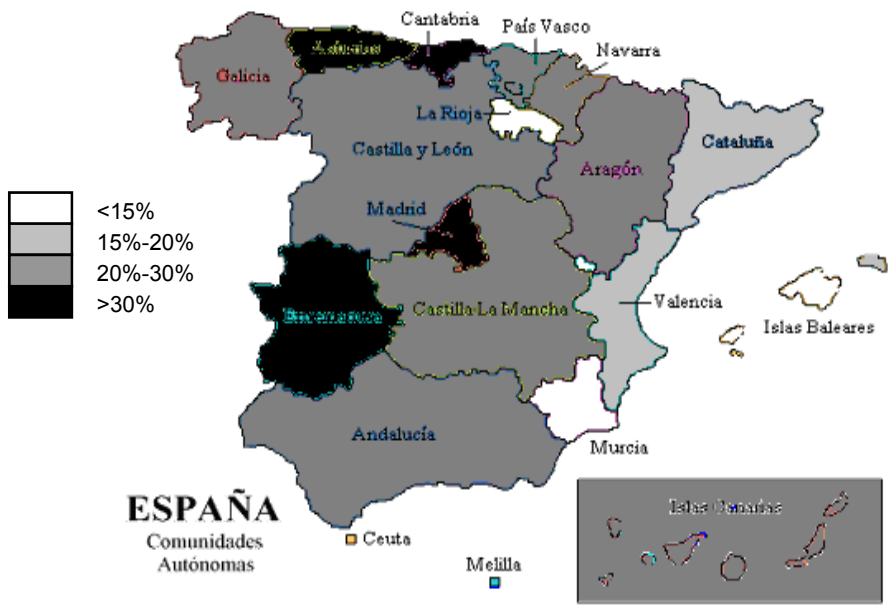

Map 3. Estimated Producer Support by AC: percentage of producers' income (average 2002-2013)

Source: Compiled by the authors.

In Figure 3 the composition of the CAP PSE is broken down by types of measure and an evaluation is made of the impact of the measures introduced in the Mid-Term Reform, especially the reduction of production-based payments and their gradual replacement by decoupled payments (single payments). Figure 3 shows the pillars on which the reform was based: a sharp drop in production-based payments (Category A), reduced payments per hectare and head of cattle (Category C) and a sharp increase in decoupled payments (Category E). 


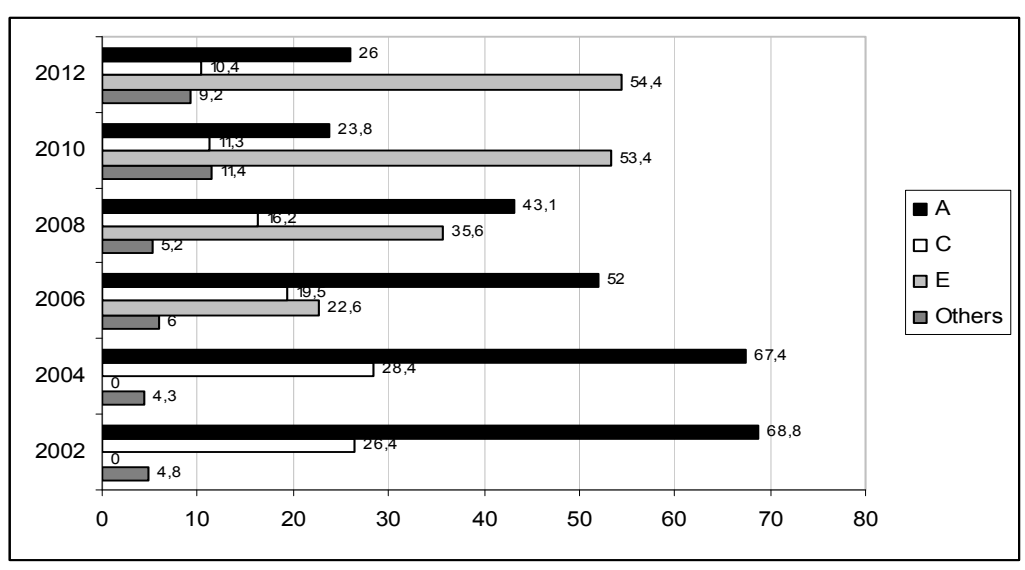

Figure 3. Percentage change in the principal CAP PSE categories in Spain

Source: Compiled by the authors.

In 2002 almost $70 \%$ of the CAP PSE consisted of production-based support and most of it was granted through prices, which is the decoupled-zero reference. After 2006 and the introduction of the single payment by the Mid-term Reform, the situation began to change. In that year the value of Category A fell to $52 \%$ (though still high due to the predominance of frontier-protection measures in the dairy and vegetable sectors, the maintenance of internal prices in products such as rice and dairy derivatives, and the predominance of direct payments to production in the Mediterranean sectors such as oil and wine, tobacco and cattle) while decoupled payments reached a value of $23 \%$. One decade later, Category A had been reduced to $43 \%$. However, this form of price and production support is still in force due to import duties, which are still the main protection in most OECD countries and explain the persistence of domestic prices higher than the world average (Note 15). The CAP PSE Category C, direct payments per hectare and head of cattle, created in 1992, and currently replaced by "green box" decoupled payments, reached a maximum in 2005 at $28.4 \%$. However, four years later it had fallen to $10.4 \%$. The reductions in Categories A and $\mathrm{C}$ were compensated for by the single payment (Category E), which represented 54.4\% of the CAP PSE in 2012 (it did not exist eight years previously).

The different starting points and the different production specialties of the territories gave rise to a series of changes of varying intensity, which allows one to speculate that the rate of adaptation to the reform of agricultural policies is faster in some regions than others, i.e. the different effects of the Mid-Term Reform and the Health Check. The greatest impact was in Aragón, both Castillas, Andalusia and Extremadura, due to the reduced weight of production-based support, compensated by higher percentages of direct payments per hectare and head of cattle or in a single payment for specializing in cereals, stock breeding or olive oil. Navarra and Asturias are closest to the average Spanish evolution and maintain their production-based support around 30\%. The weakest impact was found in Galicia, Madrid and the Mediterranean coast, where the specialization in milk and vegetables keeps their production-based support above $40 \%$.

(i) Market Price Support (MPS) and Rising World Prices

It can be seen in Table 7 that the reduction in CAP PSE was due to the reduction in MPS, which, with an annual average of $€ 4,000 \mathrm{~m}$ was reduced by $66 \%$ after 2002 (60\% in Europe) (Note 16). The drastic evolution of MPS was due not only to the change in the CAP model after 1992 but also to higher world prices. MPS is concentrated in the large production regions of Andalusia, Castilla \& León, Catalonia and Aragón, and in the fruit and vegetable producing regions of Valencia and Murcia and in milk-producing Galicia. Even though the drop in MPS is inexorable in all regions, it still survives due to the predominance of protective customs duties in the fruit and vegetable and dairy sectors, the price maintenance of rice and dairy products and to the Mediterranean products whose prices have not risen as high as those in other regions. 
Table 7. Regional Market Price Support ( $€$ million)

\begin{tabular}{|c|c|c|c|c|c|}
\hline & $\begin{array}{l}\text { MEAN ANNUAL } \\
\text { 2002-2005 } \\
\text { AGENDA } 2000\end{array}$ & $\begin{array}{l}\text { MEAN ANNUAL } \\
\text { 2006-2009 } \\
\text { CAP MID-TERM } \\
\text { REVIEW }\end{array}$ & $\begin{array}{c}\text { MEAN ANNUAL } \\
\text { 2010-2013 } \\
\text { CAP HEALTH } \\
\text { CHECK }\end{array}$ & $\begin{array}{l}\text { MEAN } \\
2002-2013\end{array}$ & $\begin{array}{l}2002-2013 \\
(\%)\end{array}$ \\
\hline & MPS & MPS & MPS & & \\
\hline GALICIA & 476.5 & 238.9 & 172.0 & 259.8 & 7.2 \\
\hline ASTURIAS (P. de) & 136.5 & 52.3 & 26.5 & 71.7 & 1,8 \\
\hline CANTABRIA & 91.9 & 30.7 & 18.6 & 47 & 1.2 \\
\hline BASQUE COUNTRY & 117.0 & 57.4 & 26.5 & 67 & 1.6 \\
\hline NAVARRA (C.F. de) & 143.4 & 81.2 & 43.5 & 89.4 & 2.2 \\
\hline LA RIOJA & 80.1 & 43.1 & 20.0 & 47.7 & 1.2 \\
\hline ARAGÓN & 525.6 & 258.1 & 127.3 & 303.6 & 7.4 \\
\hline CATALONIA & 806.6 & 459.2 & 222.8 & 496.2 & 12.1 \\
\hline BALEARIC (Islands) & 69.1 & 38.2 & 14.3 & 40.5 & 1 \\
\hline CASTILLA \& LEÓN & 1021.2 & 462.5 & 229.7 & 571.1 & 14 \\
\hline MADRID (Com.) & 138.0 & 89.9 & 34.7 & 87.5 & 2.1 \\
\hline CASTILLA LA MANCHA & 382.0 & 208.3 & 98.7 & 229.6 & 5.6 \\
\hline VALENCIA & 543.3 & 332.4 & 173.3 & 349.6 & 8.6 \\
\hline MURCIA (R. de) & 305.0 & 165.1 & 88.8 & 186.3 & 4.6 \\
\hline EXTREMADURA & 166.3 & 147.4 & 86.1 & 133.2 & 3.3 \\
\hline ANDALUSIA & 1656.8 & 905.4 & 435.0 & 999 & 24.5 \\
\hline CANARY (Islands) & 111.5 & 61.1 & 38.2 & 70.2 & 1.7 \\
\hline TOTAL SPAIN & $6,770.6$ & $3,630.8$ & $1,855.9$ & $4,085.8$ & 100 \\
\hline
\end{tabular}

Source: Compiled by the authors.

\subsection{A Small Boost to Agricultural Competitiveness}

Support for competitiveness is included in the European Rural Development policy, with an Axis 1 of structural measures designed to promote a model of agriculture based on competitive, efficient and innovative holdings. The analysis of the Spanish competitive model reveals serious weaknesses. As can be seen in Table 8, the mean value of the EAFRD Axis 1 was $€ 600 \mathrm{~m}$ annually, or $45 \%$ of the support to Rural Development (Note 17). In spite of growing by $350 \%$ between 2007 and 2013, it was only equal to $80 \%$ of the total support to Spain from the CAP TSE in 2013, figures that show the weakness of the intervention in terms of competitiveness. On a regional scale, the comparison reveals considerable differences in strategies. In general, the distribution of Axis 1 funds is concentrated in the ACs with the highest levels of public support to agriculture: Castilla \& León, Andalusia, Galicia, Castilla-La Mancha, Catalonia and Aragón, which receive between 9.5 and $15 \%$. At the other extreme, Madrid, Cantabria, The Balearics, La Rioja and The Basque Country receive less than $2.2 \%$. However, if the percentage of total CAP support destined to promote competitiveness is considered, the leaders are La Rioja, The Balearics, The Basque Country, Galicia, Catalonia and Extremadura, with percentages between 12 and $20 \%$.

When the amount of Axis 1 is divided according to its origin (see Figure 4) it can be seen that the funds provided by the EAFRD have risen continuously since 2007, with a slowdown between 2010 and 2012 due to the world economic crisis. However, the ever tighter Spanish budgets, hit hard by the crisis, have put the co-financing of the support to competitiveness in serious danger, precisely at a time in history when a more efficient use of funds is crucial. 
Table 8. Regional Axis 1 (EAFRD + national co-financing) ( $€$ million)

\begin{tabular}{|c|c|c|c|c|c|c|c|c|c|c|}
\hline & \multicolumn{7}{|c|}{ CAP AXIS 1} & \multirow{2}{*}{$\begin{array}{l}\text { MEAN } \\
2007-2013\end{array}$} & \multirow{2}{*}{$\begin{array}{l}2007-2013 \\
(\%)\end{array}$} & \multirow{2}{*}{$\begin{array}{l}\text { \% AXIS 1/TSE } \\
2013\end{array}$} \\
\hline & 2007 & 2008 & 2009 & 2010 & 2011 & 2012 & 2013 & & & \\
\hline GALICIA & 13.1 & 21.8 & 78.1 & 106.2 & 93.7 & 62.8 & 76.6 & 64.6 & 10.7 & 17.1 \\
\hline ASTURIAS (P. de) & 18.7 & 16.6 & 25.1 & 64 & 17.5 & 24.7 & 11 & 25.4 & 4.2 & 9.9 \\
\hline CANTABRIA & 3.5 & 3.5 & 4.5 & 6.4 & 12.2 & 9.2 & 9.7 & 7 & 1.2 & 11.9 \\
\hline BASQUE COUNTRY & 0 & 10.1 & 7.4 & 11.8 & 23.8 & 20 & 17.8 & 13 & 2.2 & 18.7 \\
\hline NAVARRA (C.F. de) & 21.1 & 26.4 & 25.7 & 35.2 & 33 & 37.4 & 15 & 27.7 & 4.6 & 9.3 \\
\hline LA RIOJA & 7.3 & 7.1 & 18.7 & 14.5 & 16.4 & 11.3 & 14.7 & 12.9 & 2.1 & 19.8 \\
\hline ARAGÓN & 30.5 & 84.4 & 98.9 & 50.4 & 58.8 & 40.8 & 34.4 & 56.9 & 9.5 & 5.3 \\
\hline CATALONIA & 39.5 & 68.6 & 80.9 & 43.8 & 60.8 & 47.3 & 72.2 & 59 & 9.8 & 12.0 \\
\hline BALEARIC (Islands) & 2.8 & 3.1 & 9.1 & 7.7 & 0.5 & 10.1 & 9 & 6 & 1 & 19.7 \\
\hline CASTILLA \& LEÓN & 34.9 & 57.3 & 133.4 & 126.5 & 104 & 84.4 & 104 & 92 & 15.3 & 7.9 \\
\hline MADRID (Com.) & 0 & 1.1 & 7.4 & 3 & 5.8 & 3.9 & 5.8 & 3.9 & 0.6 & 6.8 \\
\hline CASTILLA LA MANCHA & 11 & 34.6 & 110.7 & 95.3 & 83.6 & 49.3 & 59.1 & 63.3 & 10.5 & 6.0 \\
\hline VALENCIA & 9.8 & 27.9 & 31.5 & 32.8 & 38.2 & 10.5 & 26.9 & 25.4 & 4.2 & 7.0 \\
\hline MURCIA (R. de) & 0 & 4.8 & 30 & 26.8 & 19.6 & 21.3 & 21.1 & 17.7 & 2.9 & 8.1 \\
\hline EXTREMADURA & 0 & 0 & 39.1 & 52.3 & 61.5 & 55.8 & 80 & 41.3 & 6.9 & 11.9 \\
\hline ANDALUSIA & 0.6 & 12 & 22.3 & 88.3 & 86.8 & 148.3 & 123.1 & 68.8 & 11.4 & 5.6 \\
\hline CANARY (Islands) & 0 & 0 & 18 & 21.5 & 43 & 15.8 & 20.1 & 16.9 & 2.8 & 5.9 \\
\hline TOTAL SPAIN & 193 & 379 & 741 & 787 & 759 & 653 & 701 & 601.7 & 100 & 8.2 \\
\hline
\end{tabular}

Source: Compiled by the authors.

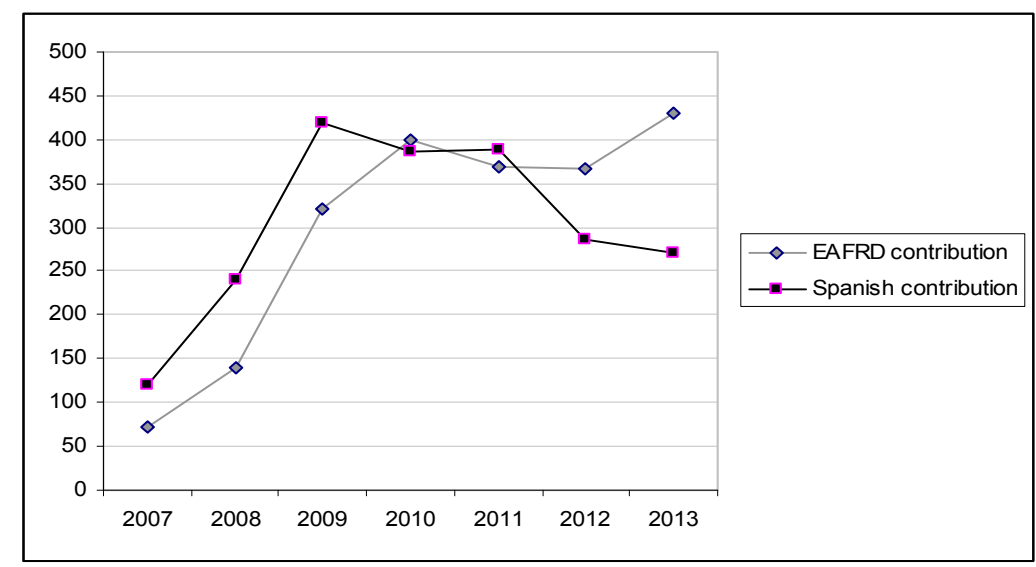

Figure 4. Evolution of Axis 1, EAFRD contribution and Spanish co-financing ( $€$ million)

Source: Compiled by the authors.

\section{Discussion}

The intense reform of the CAP has meant a profound change in the model of support to European agriculture. There is no doubt that the transfers to agriculture by the EU are being increasingly decoupled from production, to ensure their compatibility with the multilateral system of commercial rules. This modification of the financing paradigm began in 1992 with the MacSharry Reform, continued with the Agenda 2000 and was consolidated by the decisions taken in the Mid-Term Review of 2003. The 2009 Health Check fortified the 2003 Reform by further decoupling aids and limiting specific aids and by demanding greater responsibility from farmers.

The results obtained in this study for the different Spanish regions by calculating the agricultural support indicators backed by the OECD (PSE, GSSE and TSE) show that the steps in the reform of the CAP up to the single payment in 2003 have not involved significant changes apart from the dismantling of the market intervention mechanisms, since they have allowed the status quo to be maintained in both the overall level of the 
transfers, whose apparent reduction is no more than the reflection of the rise in world prices, and in their territorial distribution. This latter aspect is highly unequal in Spain due to the development of the CAP itself, the diversity of products and the use of historic references to fix the value of decoupled payments to holdings. Thus, this work calculates the annual average CAP transfer to Spain since 2002 as $€ 11100 \mathrm{~m}$ ( $€ 8,500 \mathrm{~m}$ in 2013), with most of the aid going to Andalusia, Castilla \& León, Castilla-La Mancha and Catalonia, due to the greater relative weight of CAP support to the stock-rearing, cattle, wine, cereals and olive oil sub-sectors. This highlights the difference between the (highly subsidized) continental agriculture regions and the fruit and vegetable growing regions, which do not receive the same volume of transfers, and include the dairy regions, which are tied to market-price support. When the Spanish contribution is included, the figures rise by a little over $10 \%$.

As regards the total value of the aids received, this study has shown that the $€ 600 \mathrm{~m}$ spent annually on incentives to make holdings more competitive (less than $5 \%$ of total public support) is insufficient and leaves Spanish producers in a precarious position, especially the smallest. Of the annual $€ 600 \mathrm{~m}$, the Spanish contribution to co-financing is in serious danger, as are the aids in other areas, due to the sharp cuts in public spending caused by the economic crisis and the fact that other areas have been given higher priority. Also, their distribution by regions is very unequal and reveals the wide differences in the strategies of the different autonomous communities. La Rioja, The Balearics, The Basque Country, Galicia, Catalonia and Extremadura encourage competitiveness by assigning between 12 and $20 \%$ of their available funds to this end.

From the above it can be seen that not enough is being done in Spain to promote competitiveness. There is no doubt that direct payments make up the bulk of the CAP, due to their budgetary importance (over two thirds of the agricultural funds) and they have always been at the center of attention in debates on the CAP. The figures cited in this paper are aimed at stimulating the political debate on competitiveness, since in the authors' opinion it is one of the biggest challenges to the rural development policies.

This work has shown that until 2013 agricultural transfers in Spain have depended on the historic CAP support model and have had little to do with remunerating farmers for the public service they provide, or with restructuring, modernizing and adapting to a more competitive environment. It would appear that the new CAP 2014-2020, which includes environmental objectives in direct payments, is the beginning of the end of the status $q u o$ and historical references. As always, Spain has again opted for reducing to the minimum the wide differences in the size of the payments to its farmers. Spanish agriculture now faces the need to adapt itself to a difficult and ever-changing international situation. The CAP 2014-2020 Rural Development programs provide the basis for implementing the necessary investment on a regional scale, to modernize holdings in order to boost production and improve environmental aspects, increase incomes, employment, standards of living, the economic and social cohesion of rural communities, and put an end to the long-term tendency of disinvestment that limits rural development. The national, regional and local administrations have a responsibility to plan alternative economic strategies for the different territories and provide them with sufficient funds for their needs, in our opinion a crucial issue.

Future lines of research will go deeper into the results obtained in the present study. The new CAP 2014-2020 direct payments system, which came into force in 2015, needs further analysis from the regional perspective (basic, green, young farmers, coupled direct payments, aids to naturally disadvantaged zones, and redistributive payments). Bearing in mind that Spain has opted for a national model that does not include redistributive payments or aids to disadvantaged areas, the aim of the analysis will be to evaluate the degree of convergence obtained by these payments with respect to the previous situation and their impact on the regions themselves, on the sub-sectors, on individual holdings, etc. In short, the aim will be to answer the question of whether Spain has made any progress towards a more equitable system of payments. Another natural continuation of this line of research will be to look for viable strategies to boost competitiveness and innovation in the agriculture of the different ACs, including the development of new products, processes and technologies, the selection of successful experiences and assessing their suitability for implementation in other regions.

\section{References}

Aggelopoulos, S., Pavloudi, A., \& Chioteris, C. (2014). Evaluation of the implementation of agricultural investments under the Rural Development Programme (RDP) 2007-2014. In D. Vrontis, Y. Weber, \& E. Tsoukatos (Eds.), 7th Annual EuroMed Conference of the EuroMed-Academy-of-Business. Kristiansand, Norway.

Anders, S., Harche, J., Herrmann, R., \& Salhofer, K. (2004). Regional income effects of Producer Support under the CAP. Cahiers d'Economie et Sociologie Rurales, 73(4), 103-122. 
Andrés, S., \& García, J. M. (2010). Indicadores de apoyo público a la agricultura: España y sus comunidades autónomas en el contexto de la OCDE. Revista de Economía Mundial, 25, 159-190.

Andrés, S., \& García, J. M. (2016). Reparto regional en España de la ayuda agrícola según la Organización Mundial de Comercio (2002-2010). Revista de la Facultad de Ciencias Agrarias, 48(2), 121-139.

Atance, I. (2006). El Desarrollo Rural. In J. M. García (Ed.), La Reforma de la Política Agraria Común. Preguntas y respuestas en torno al futuro de la agricultura (pp. 131-154). Madrid: Eumedia \& MAPA.

Atance, I. (2007). Política agraria para una agricultura multifuncional: análisis de la PAC reformada frente a la multifuncionalidad. In J. A. Gómez, \& J. Barreiro (Eds.), La multifuncionalidad de la agricultura en España (pp. 91-106). Madrid: Eumedia \& MAPA.

Atance, I., \& Gómez, J. A. (2004). Identificación de objetivos públicos para el apoyo al sector agrario. Revista Española de Estudios Agrosociales y Pesqueros, 203, 49-84.

Blanco, M., García, S., \& Bardají, I. (2011). El modelo de ayudas directas en la PAC post-2013: Análisis de impactos de escenarios potenciales. Economía Agraria y Recursos Naturales, 11(2), 83-108. https://doi.org/ 10.7201/earn.2011.02.04

Blandford, D. (2005). Imposing WTO disciplines on domestic support: An assessment of the Doha Round Approach. Economía Agraria y Recursos Naturales, 5(9), 3-26. https://doi.org/10.7201/earn.2005.09.01

Buckwell, A. (2009). Elements of the post 2013 CAP. Workshop on "The future of the CAP 2013", 10th November, European Parliament: COMAGRI.

Castillo, J. S., \& Ramos, F. (2010). Desarrollo Rural y futuro de la política rural en la UE. In J. M. García, \& J. A. Gómez (Eds.), Chequeo Médico de la PAC, y perspectivas de la Política Agraria Común tras 2013 (pp. 177-212). Madrid: Eumedia y Ministerio de Medio Ambiente, Medio Rural y Marino.

Cejudo, E., \& Maroto, J. C. (2010). La reforma de la PAC de 2003: Desacoplamiento, condicionalidad, modulación y desarrollo rural. Scripta Nova, XIV(318), 123-145.

Cofas, E., \& Toma, E. (2014). Territorial inequality distribution of CAP funds designated to increase the competitiveness of agri-food and forestry Romanian sectors. In K. S. Soliman (Ed.), 23rd International-Business-Information-Management-Association Conference on Visio 2020: Sustainable Growth, Economic Development, and Global Competitiveness. Valencia, Spain.

Compés, R., \& García, J. M. (2009). Reforma de la PAC y agricultura española: Alternativas y oportunidades para España. Madrid: Fundación Alternativas.

Compés, R., \& García, J. M. (2013). The Common Agricultural Policy in 2012, in the state of the European Union 2012 (pp. 129-13). Friedich Ebert Stiftung.

Czyzewski, A., \& Stepies, S. (2011). Common Agricultural Policy of the EU after 2013 and the interests of the Polish agriculture. Ekonomista, 1, 9-36.

Erjavec, E., Chantreuil, F., Hanrahan, K., Donnellan, T., Sapultra, G., Kozar, M., \& Van Leeuwen, M. (2011). Policy assessment of an EU wide flat area CAP payment system. Economic Modelling, 28(4), 1550-1558. https://doi.org/10.1016/j.econmod.2011.02.007

European Commission. (2001). Study on the impact of community agricultural policies on economic and social cohesion. Brussels: Directorate General for Regional Policy.

European Spatial Planning Observation Network. (2005). ESPON Project 2.1.3: The territorial impact of CAP and Rural Development Policy. Arkleton Institute for Rural Development Research, University of Aberdeen.

Fragoso, R., Marques, C., Lucas, M. R., et al. (2011). The economic effects of common agricultural policy on Mediterranean montado/dehesa ecosystem. Journal of Policy Modelling, 33(2), 311-327. https:/doi.org/ 10.1016/j.jpolmod.2010.12.007

García, J. M., \& Andrés, S. (2007). Estimación del apoyo comunitario a la agricultura de las Comunidades Autónomas. Revista Española de Estudios Agrosociales y Pesqueros, 213(1), 179-206.

García, J. M., Möhlendick, B., \& Soriano, V. (1994). Gasto público y sistema autonómico. La política agraria autonómica a examen. Valencia: Generalitat Valenciana, Serie Estudios.

Gocht, A., Britz, W., Ciaian, P., \& Paloma, S. (2011). EU-wide distributional effects of EU direct payments harmonization analyzed with CAPRI. EAAE 2011 Congress "Change and Uncertainty". Zurich. 
Hansen, H. (2005). Effects of agricultural policy measures on gross transfers to farmers: Intertemporal and interregional evidence from the CAP. XIth Congress of the European Association of Agricultural Economists: 'The Future of Rural Europe in the Global Agri-Food System. Copenhagen, Denmark.

Hermans, C. M. L., Geijzendorffer, I. R., Ewert, M., et al. (2010). Exploring the future of European crop production in a liberalised market, with specific consideration of climate change and the regional competitiveness. Ecological Modelling, 221(18), 2177-2187. https://doi.org/10.1016/j.ecolmodel.2010. 03.021

Horlings, L. G., \& Marsden, T. K. (2014). Exploring the 'New Rural Paradigm' in Europe: Eco-economic strategies as a counterforce to the global competitiveness agenda. European Urban and Regional Studies, 21(1), 4-20. https://doi.org/10.1177/0969776412441934

MAPA. (2004). Territorialización de los apoyos públicos. Libro Blanco sobre la Agricultura y el Desarrollo Rural. Madrid: MAPA.

Massot, A. (2010). La revisión presupuestaria como marco general de la PAC post 2013. In J. M. García, \& J. A. Gómez (Eds.), Chequeo Médico de la PAC, y perspectivas de la Política Agraria Común tras 2013 (pp. 105-128). Madrid: Eumedia y Ministerio de Medio Ambiente, Medio Rural y Marino.

Massot, A. (2013). La PAC y la sostenibilidad de la agricultura europea en la era global. In J. A. Goméz, \& E. Reig (Eds.), La sostenibilidad de la agricultura española (pp. 235-275). Almería: Cajamar Caja Rural.

OECD. (2007). Agricultural policies in OECD countries: Monitoring and evaluation 2007. Retrieved from $\mathrm{http} / / / \mathrm{www} .0 e c d . o r g / \operatorname{document} / 59 / 0,3343$,en_2825_494504_39551355_1_1_1_1,00.html

Philippidis, G. (2005). Agricultural trade liberalisation in the Doha Round. Economía Agraria y Recursos Naturales, 5(10), 41-68. https://doi.org/10.7201/earn.2005.10.03

Popov, R. (2012). Medium-term priorities of Bulgarian agricultural policy. Bulgarian Journal of Agricultural Science, 18(1), 1-18.

Regidor, J. G., \& Troitiño, M. A. (2008). El nuevo desafío rural. In J. G. Regidor (Ed.), Desarrollo Rural sostenible: Un nuevo desafio (pp. 19-42). Madrid: Ministerio de Medio Ambiente, Medio Rural y Marino.

Sumner, D. A., \& Brunke, H. (2003). Commodity policy and California agriculture. In J. B. Siebert (Ed.), Forthcoming in California agriculture: Issues and challenges. University of California, Giannini Foundation.

Tarditi, S., \& Zanias, G. (2001). Common Agricultural Policy. In R. Hall, A. Smith \& L. Tsoukalis (Eds.), Competitiveness and cohesion in EU policies (pp. 179-216). Oxford University Press.

Velázquez, B. (2008). The single payment scheme in the impact assessment of the CAP Health Check. $109^{\text {th }}$ EAAE Seminar "The CAP after the Fischler Reform: National implementations, impact assessment and agenda for future reforms", Viterbo, Italy.

Walkenhorst, P. (2003). Regional diversity, policy targeting and agricultural producer support in Switzerland. Jahrbuch für Regionalwissenschaft, 23(2), 141-153.

Zahrnt, V. (2009). Public money for public goods: Winters and losers from CAP reform. Working Paper No. 08/2009. London: ECIPE.

Zanias, G. P. (2002). The distribution of CAP benefits among member states and the impact of a partial re-nationalisation: A note. Journal of Agricultural Economics, 53(1), 108-112. https://doi.org/10.1111/ j.1477-9552.2002.tb00009.x

Zasada, I., \& Piorr, A. (2015). The role of local framework conditions for the adoption of rural development policy: An example of diversification, tourism development and village renewal in Brandenburg, Germany. Ecological Indicators, 59, 82-93. https://doi.org/10.1016/j.ecolind.2015.02.002

\section{Notes}

Note 1. Horlings and Marsden (2014) have explored the "New Rural Paradigm" in Europe.

Note 2. http://www.oecd.org/tad/agricultural-policies/monitoring-and-evaluation.htm

Note 3. http://www.oecd.org/tad/agricultural-policies/psemanual.htm

Note 4. http://www.oecd.org/tad/agricultural-policies/producerandconsumersupportestimatesdatabase.htm 
Note 5. For 2005 and 2006, the value of co-financed development measures were supplied by the Subdirección General de Relaciones Internacionales y Asuntos Comunitarios of the MAGRAMA.

Note 6. From January 12007 the classification of agricultural Funds was modified, with the distribution of agricultural policy expenditure between the European Agricultural Guarantee Fund (EAGF) and the European Agricultural Fund for Rural Development (EAFRD).

Note 7. These actions were mostly related to modernizing holdings and setting up young farmers.

Note 8 . Average annual public spending associated with the priority axes of agricultural interest in the National Strategic Reference Framework 2007-2013.

Note 9. The PRA, SAU, UTA and GDP values were obtained from the National Statistics Institute (INE).

Note 10. OECD Database 1986-2015 (see footnote 3).

Note 11. OECD Database 1986-2015 (see footnote 3).

Note 12. OECD Database 1986-2015 (see footnote 3).

Note 13. The POSEICAN program in 1991 laid down the legal basis of the Canary Islands relationship with the EU due to their remoteness, territorial fragmentation and special economic and fiscal characteristics.

Note 14. OECD Database 1986-2015 (see footnote 3).

Note 15. In the EU some products are protected by high customs duties (maximum admissible duties according to the agreements with the WTO). These high protection measures are in products such as sugar (mean customs duty $129 \%)$, meat (67.5\%), dairy products (55.9\%) and flour (44.4\%). In fruit and vegetables a system of entry prices is applied that involves additional duties due to European protection from external competition.

Note 16. See OECD Database 1986-2015.

Note 17. The other EAFRD Axes are: Axis 2-Improvement of the Environment and the Countryside by means of Aids to Land Management; Axis 3-Improvement of Quality of Life in Rural Areas and Promotion of Diversification of Economic Activities; Axis 4-LEADER; Axis 5-Technical Assistance.

\section{Copyrights}

Copyright for this article is retained by the author(s), with first publication rights granted to the journal.

This is an open-access article distributed under the terms and conditions of the Creative Commons Attribution license (http://creativecommons.org/licenses/by/4.0/). 